\title{
Application Of Criminal Sanctions Against Gambling Business Crime In The Kudus State Court Criminal Law And Policy In The Bill Book Of Laws Based On The Value Of Criminal Justice
}

\author{
Jajang Wiwoko ${ }^{1}$ and Eko Soponyono ${ }^{2}$
}

Abstract. The interest and research in this paper are to determine the application of the Criminal Sanctions Against Perpetrators of the Crime of Gambling in the Kudus District Court in the Criminal Law and Policy In the draft the Code of Penal The ValueBased Criminal Justice.

This research is empirical legal research, the research is based on Application of Criminal Sanctions Against Perpetrators of the Crime of Gambling in the Kudus District Court in the Criminal Law and Policy In the draft the Code of Criminal Justice Based Values were analyzed quantitatively.

The application of criminal sanctions against perpetrators of criminal acts gambling in the District Court of the Kudus

In its decision 89 / Pid.Sus / 2016 / PN.Kds. Judges used a single indictment, namely Article 310 paragraph (4) of Act No. 22 of 2009 on Traffic and Transportation where elements of the indictment has been taken as proved by the judges. Where, between the act and the elements of each to the correct article. And by saving writer application of the substantive law in the case has been in accordance with the criminal law in Indonesia.

Decision No. 89 / Pid.Sus / 2016 / PN.Kds. decisions proccess made by the judges opinion, Writers are in accordance with the applicable law as described by the author before, based on at least two a lack of legal evidence, where in the cases studied author, who used the judge evidence is witness testimony, evidence, letter post mortem and the testimony of the defendant.

Keywords: Analysis of Law; Criminal Witness; Traffic Accidents.

\section{Introduction}

Indonesia is a country of law $^{3}$ as stated in the Constitution of the Republic of Indonesia of 1945 (Constitution NRI 1945), which governs all aspects of community life in Indonesia. It is set firmly in the elucidation of the Constitution NRI in 1945 that "the Republic of Indonesia based on law (rechsstaat), not based on power alone (machstaat)". The law here has a particular significance in the aspects of life as a guide humans behave in relation to other human beings.

In a state of law, the law serve as the main basis in moving every joint life of society, nation and state. In addition, the law also be used as a means of social control, so the law is there

\footnotetext{
${ }^{1}$ Student of Master of Law, Universitas Islam Sultan Agung Semarang and Members of the Indonesian National Police (Polri), email: bbony77@yahoo.com

${ }^{2}$ Faculty of Law Universitas Islam Sultan Agung

${ }^{3}$ Article 1 (3) of the Constitution of the Republic of Indonesia of 1945
} 
to keep the community can remain in the patterns of behavior that is accepted universally. In such functions, the Act only maintain what was there and accepted in society but beyond that the law is still able to function the other is to make changes in society.

Judging from national interests, the organization of gambling has a negative excesses and moral and mental harm to the public, especially the younger generation. The increase in the mode of the crime of gambling that is higher can be seen from the proliferation of types of gambling, such as toggle, gambling tail, gambling white coupons, On line gambling even wearing sophisticated technology by telephone, internet or SMS (short message service) and WA (Whats App).

Gambling in the historical process of generation was not easy to eradicate. Despite the fact also shows that the results obtained by the government gambling could be used for development efforts, as an example, in Jakarta during the administration of Governor $\mathrm{AH}$ Sadikin that legalized gambling and prostitution. However, in spite of the negative effects of gambling outweigh the positive impacts. Therefore, the government and law enforcement officials concerned must take firm action so that people stay away and finally stopped gambling. ${ }^{4}$

Based on the matters described above, the researchers intend to conduct a study on problems so in terms of rule of law and to maintain public order, the police as law enforcement officials and the state, plays a role in tackling the crime of gambling with the title as follows:

"Application of Criminal Sanction Against Perpetrators of the Crime of Gambling in the District Court of the Kudus and Policy of Criminal Law in the draft the Code of Penal The Value-Based Justice." Based on description it can be formulated research problem is: How does the application of criminal sanctions against perpetrators criminal gambling in the District Court of the Kudus, How the application of criminal sanctions against perpetrators of the crime of gambling in the Kudus District Court has not based the values of justice, how policy criminal sanctions against perpetrators of criminal acts gambling in the draft statute book of criminal law based on values of justice?

\section{Research Methods}

This research approach is juridical-empirical approach. Yudiris approach is used to analyze the regulations related to the Criminal Law currently used empirical approach to legal mengalisis seen as patterned behavior of people in public life who constantly interact and relate in the community aspects. ${ }^{5}$

\section{Discussion}

2.1 The Application Of Criminal Sanctions Against Perpetrators Of Criminal Acts of Gambling In The District Court Of The Kudus

\footnotetext{
${ }^{4}$ Media Hukum, hukum online.com, Internet downloads dated October 18, 2018

${ }^{5}$ Bambang Suggono, Metode Penelitian Hukum, PT Raja Grafindo Persada, Jakarta, 2003, p. 23
} 
Laws which has regulated the crime of gambling online explains who should be held accountable if committed the crime of gambling, namely the Penal Code, Act No. 7 of 1974 on Control Gambling, Act No. 11 of 2008 on Information and Electronic Transactions, and Government Regulation No. 9 of 1981 on the implementation of the Gambling Control. In these regulations can be summed anyone who may be sanctioned or held accountable for criminal namely:

- Hold him or give it as a living gambling. Thus, a dealer or other person as the company opened gambling. People who intervened in this case is also punishable. Here do not need gambling in a public place or to the public, although in a closed or closed circle is sufficient, as long as gambling has not yet received permission from the authorities;

- Deliberately held or give the opportunity to gamble to common. There is no need as a living, but it must be in a public place or in a place that can be visited by the public. If it has no permission from the authorities, it is not punished;

- In playing gambling as an occupation;

- Shall be punished as a criminal

- Those who did, were told to do, and were involved in the act;

- Those who give or promise anything to the abuse of power or dignity, by force, threat or deception, or by providing an opportunity, means or information, intentionally encourage others to do the deed.

- To advocate, only acts that deliberately encouraged taken only into account, and its after math.

- Any person deliberately without the right to distribute and / or transmitting and / or make the inaccessibility of Electronic Information and / or Electronic Documents which have a gambling charge.

\subsection{The Application Of Criminal Sanctions Against Perpetrators Of Criminal Acts Of Gambling In The Kudus District Court Has Not Based The Value Of Justice}

Regarding consideration of Judges, the accused who had committed the crime of negligence will first be reviewed and considered by the judges whether the acts of which the accused defendant has met the elements of Article 310 paragraph (4) of Act No. 22 of 2009 which has indicted them:

Considering that the defendant has been charged with Article 310 paragraph (4) of Act No. 22 of 2009 whose elements are as follows: Every person; Driving a motor vehicle due to negligence; The lead others died.

Considering that the next Assembly will consider whether the defendant has fulfilled not know the provisions of Article 310 paragraph (4) of Act No. 22 of 2009 is as follows:

The judge in the criminal case investigation and truth seeking material based on the facts revealed in the trial, and cling to what is defined in the indictment the prosecutor.

Based on the position of the case as described above, it can be concluded in accordance with the provisions of either the law of formal criminal and criminal law material and conditions 
that can dipidananya an accused, it is based on the proceedings, where evidence presented prosecutors, including captions plus fit together witness testimony.

\subsection{Consideration of Criminal Justice in the Case Dropped Decision No. (89 / Pid.Sus / 2016 / PN.Kds)}

In dropping Criminal, judges should be based on two legal evidence which then of the two judges that evidence gained confidence that the indicted criminal offense actually occurred and the defendant who did it, it is stipulated in Article 183 Criminal Procedure Code.

Verification system under Article 183 Criminal Procedure Code is called negative-Wettelijke Stelsel or authentication system according to the legislation that is negative.

Said verification system in the Criminal Code as a system of proof (Lamintang and Theo Lamintang) ${ }^{6}$ because:

- Wettelijk Known or statutory due to the evidence, the law that determines the type and amount of evidence that must be present;

- Called negative because of the types and amount of evidence prescribed by the law can not make the judge must impose criminal for a person accused, if the types and amount of evidence that has not been able to give rise to the belief the judge that a crime was actually occurred and that the defendant was guilty of the criminal offense.

Aside from what the author described above, which need to be done by the judge is to be dipidananya offender, required that the offense is doing is fulfilling the elements specified in the Act No. 79. Viewed from the angle of the prohibited acts, a person will be accountable for the actions of such, when such actions are against the law and there is no justification or omission against the law for the criminal nature of his accomplishments. And from the standpoint of the ability of responsible then the only person who is able to be responsible to be accountable for his actions. and there is no justification or omission against the law for the criminal nature of his accomplishments. And from the standpoint of the ability of responsible then the only person who is able to be responsible to be accountable for his actions. Under these conditions, criminal liability or fault under criminal law consists of three terms (Moeljatno) ${ }^{7}$ that is :

- Ability responsible or accountable of the creator;

- The existence of an unlawful act that is a mental attitude of the offender related to behavior, namely: Intentional; Attitude inadvertent or negligent.

- There is no justification or reason that abolishing criminal liability for the creator.

The ability to discriminate between good deeds and bad, is a reasonable factor that can distinguish acts that are allowed and which are not. And the ability to determine his will according to the conviction of the merits of such actions is a feelgood factor that is able to customize its behavior with conviction on what is allowed and what is not.

\footnotetext{
${ }^{6}$ P.A.F. Lamintang. 1997.Dasar-dasar Hukum Pidana di Indonesia. PT. Citra Aditya Bakti : Bandung, p. 409-409

${ }^{7}$ Moeljatno, L. 2002. Asas-asas Hukum Pidana. Rineka Cipta : Jakarta. p. 6
} 
As a consequence of two of these things then of course people are not able to determine his will according to the conviction of the good and bad deeds, he does not have an error when committing a crime, these people can not be justified.

In the Criminal Code's ability problems are responsible for in Article 44 paragraph 1 of the Criminal Code, which reads: "Whoever does a deed that is not accountable to him because his soul defect in growth or impaired due to disability, not convicted".

To determine their liability, the maker someone committed a crime there must be an element of tort.

Nature against the law when linked with the state of psychic (soul) maker of the offenses that do may be deliberate (opzet) or due to negligence (culpa). In this case the judge used the theory of negligence because negligence is a form of error which results can be held responsible for the actions of someone who does, as stated in Article 359 of the Criminal Code which states as follows:

Whoever due to negligence causes the death of another person shall be sentenced to imprisonment of five years or a maximum imprisonment of one year.

Next to determine whether or not a person sentenced is whether there is a justification or an excuse.

With the elimination of one of the basic form of the basic criminal an act justifying the loss of properties against the law, so that it becomes legal / allowed, making can not be termed as a criminal. But if there is a basic form of the basic eraser forgiving then an action is still against the law, but the maker is unforgivable, so it was not sentenced.

Basic eraser criminal or could also be called the reasons for disregarding the criminal offense is contained in Book I of the Criminal Code, namely basic Justifiers: Bela enforced Article 49 paragraph 1 of the Criminal Code, a state of emergency, the implementation of the legislation of Article 50 of the Criminal Code, the command post of Article 51 paragraph 1 of the Criminal Code.

In the decision No. 122 / Pid.B / 2013 / PN.Kds.The decision process carried out by the judges according to the opinion author has been in accordance with the applicable law as described by the author before, based on at least a lack of two legal evidence, which in the case under study author, the evidence used judges are witness testimony, evidence, letter post mortem and the testimony of the defendant. Then consider about criminal responsibility, in this case the panel of judges based on the facts that arise in the trial judge that the defendant is accountable for acts committed by the consideration that the time of his actions the defendant aware of the consequences caused, the offender in performing actions that are in condition healthy and capable to consider his actions.

In addition to the above, the judge did not see any justification or an excuse to be a reason for the removal of the criminal acts committed by the defendant. Similarly, the Public Prosecutor, the judges only see things that are incriminating is the act of the defendant caused others died and cause grief for the families of the victims. And the things that relieve namely:

- The defendant has not been convicted; 
- The defendant polite in court and admit frankly his act and sorry for his act;

- The defendant has given cash compensation to the families of the victims who died were admitted honestly deeds done by the Makassar Court Judge stated that the defendant has the elements to the correct formulation of the offense contained in Article 310 paragraph (4) of Act No. 22 of 2009 regarding Traffic and Road Transportation.

The elements of the crime of negligence under Article 310 paragraph (4) of Act No. 22 of 2009 on Protection of Children is as follows:

- Each person;

- Driving a motor vehicle due to negligence;

- The result of others died.

In connection with the above problems, the authors conducted an interview with a Kudus District Court judge mr. Yasri, $\mathrm{SH}^{8}$ (Interview dated December 12, 2013), which at the time as the presiding judge deciding the case explained that:

The application of criminal law judges conducted appropriate due to the correct formulation of the elements of the offense actions already, which applied Article 310 paragraph (4) of Act No. 22 of 2009.

As for the effectiveness of the sanctions against the crime of omission of traffic in the decision ` 122 / Pid.B / 2013 / PN.Kds.is according to Mr. Iketut Mardika, SH ${ }^{9}$ (Interview dated July 12, 2017) which states that:

Convict the accused with imprisonment for two (2) years and a fine of Rp. 500.000, - (five hundred thousand rupiah) provided that if the fine is not paid in compensation to imprisonment for 3 (three) months.

In the imposition of punishment through the process. Prior to this process is the role of a judge is very important. He concretize criminal sanctions contained in a regulation to convict the defendants. So the sentence imposed is expected to resolve the conflict or disagreement and also bring a sense of peace in society.

Criminalization is not intended to give the suffering and should not degrading, but is giving meaning to the Indonesian legal system. Although crime is essentially an agony, but the purpose of sentencing is not intended to give the suffering and should not degrading.

\section{Closing}

\subsection{Conclution}

- Liability criminal laws driver of the vehicle against the negligence of the traffic that resulted in the death of the victim diatrur in Article 22 paragraph 4 letter c of Act No. 22 of 2009 about traffic and road transport Punishment has been progressing, ie from goal retaliation moving towards coaching for the defendant back into a human good and useful to society.

\footnotetext{
${ }^{8}$ Kudus District Court Judge mr. Yasri, SH (Interview dated July 19, 2017)

${ }^{9}$ Kudus District Court Judge mr. Iketut Mardika, SH (Interview dated July 12, 2017)
} 
- The application of criminal law is immaterial to the traffic negligence causing death of the victim is an element of death or serious injury victims are met the decision No. 89 / Pid.Sus / 2016 / PN.Kds. Judges forum use a single indictment, namely Article 310 paragraph (4) of Act No. 22 of 2009 on Traffic and Transportation where elements of the indictment has been taken as proved by the judges. Where, between the act and the elements of each to the correct article. And by saving Writer application of the substantive law in the case has been in accordance with the criminal law in Indonesia.

- The judge in the convict consideration in the decision No. 89 / Pid.Sus / 2016 / PN.Kds consideration of criminal responsibility, in this case the judges based on facts arising in the trial judge that the defendant is accountable for acts committed by the consideration that at the time of his actions the defendant aware of the consequences caused, the offender in performing actions that are in a healthy condition and capable to consider his actions. There is an element against the law, and the absence of a criminal deletion reason.

\subsection{Suggestion}

- The judges in the decision by the criminal provisions governing the elimination of criminal sanctions imposed are not proportional to the crime, and suffering experienced by the victim's family for life. However, when considering have any peace between the families of the victims and the accused, then the real criminal is no longer much meaning for the families of the victims. Therefore, it has been their peace means the victim's family to forgive and forgive the accused.

- The General Prosecutor should be thorough and meticulous in preparing the indictment, given the indictment is the basis for the judge to impose or not impose punishment against perpetrators who are confronted in court, in addition, must also have the knowledge or science of law well, not only the law formally, but also materially law so that no one in deciding which actions are in accordance with the elements as indicted.

- The judge did not necessarily warrant based on the Public Prosecutor in Criminal dropping, but on the two legal evidence coupled with the judge's conviction. Judges should be more sensitive to seeing what facts that arise during the trials, so that from the fact that these arise, leading to the judge's conviction that the defendant may or may not be convicted.

\section{Bibliography}

[1] Achmad Ali. 2002, Menguak Tabir Hukum, Edisi kedua. PT Toko Gunung Agung tbk, Jakarta.

[2] Amir llyas. 2012. Asas-asas Hukum Pidana. Rangkang Education, Yogyakarta.

[3] Bambang Sugugono, 2003, Metode Penelitian hukum, PT Raja Grafindo Persada, Jakarta.

[4] Leden Marpaung. 2005. Asas, Teori, Praktik Hukum Pidana. Sinar Grafika : Jakarta.

[5] Moeljatno,L. 2002. Asas-asas Hukum Pidana. Rineka Cipta : Jakarta.

[6] M. Solly Lubis. 2002, Ilmu Negara, Cetakan Ke-5. Mandar Maju : Bandung. 
[7] P.A.F. Lamintang. 1997..Dasar-dasar Hukum Pidana di Indonesia. PT. Citra Aditya Bakti : Bandung.

[8] Pandang Rusli Effendy. 1989. Asas-Asas Hukum Pidana. Lembaga Kriminologi Unhas : Ujung.

[9] Soerjono Soekamto, 1987, Pengantar Peneltian Hukum, Universitas Indonesia Press, Jakarta.

[10] Wirjono Prodjodikoro 2003. Asas-Asas Hukum Pidana di Indonesia. Refika Aditama , Bandung.

[11] --------. 2003 Asas-Asas Hukum Pidana di Indonesia. Refika Aditama, Bandung.

[12] Y. Kanter dan S.R. Sianturi,. 1982, .Asas-Asas Hukum Pidana disertai Pembahasan Beberapa Perbuatan Pidana Yang Penting, PT Tiara Ltd : Jakarta. 